Sławomir Soczyński orcid.org/0000-0002-2664-6833

Uniwersytet Papieski Jana Pawła II w Krakowie

slawomir.soczynski@upjp2.edu.pl

\title{
CORPORATE DIGITAL RESPONSIBILITY W PRZEDSIĘBIORSTWACH MEDIALNYCH
}

\section{Abstract \\ CORPORATE DIGITAL RESPONSIBILITY IN MEDIA ENTERPRISES}

The impact of digitization on our lives is constantly growing. Benefits resulting from automation, data analysis, Artificial Intelligence (AI) and machine learning are increasingly more visible in everyday life. However, they give rise to previously unknown ethical and social problems. Many of them have already been described in literature. A new concept of Corporate Digital Responsibility (CDR), drawing on Corporate Social Responsibility, aims at developing precise guidelines and good practices, which will influence responsible business activity in the digital world. The purpose of this article is to present the sole concept of CDR and to ground it in the context of the media, which constitute an important part of the economy relying on new technologies.

Keywords: corporate digital responsibility, digital technologies, ethics, organisational culture, privacy

JEL: L82, M14

\section{Wprowadzenie}

Postępująca transformacja społeczeństwa w kierunku jego cyfryzacji jest faktem. Proces ten dokonuje się na różnych płaszczyznach życia i gospodarki. Obejmuje sferę ekonomiczną, społeczną i kulturową, stając się istotnym czynnikiem rozwoju współczesnego społeczeństwa informacyjnego. Korzyści wynikające z niego są zauważalne zarówno w obszarze rozwoju osobistego (chociażby poprzez wzrost kompetencji informacyjno-komunikacyjnych), jak i w dynamicznie rozwijającej się gospodarce, która dzięki cyfryzacji staje się efektywniejsza. Automatyzacja w przemyśle, zwiększone możliwości zbierania i analizowania danych, powstanie i rozwój 
sztucznej inteligencji, rzeczywistość wirtualna i rozszerzona, internet rzeczy, robotyka czy technologia blockchain to powiązane z nią osiągnięcia, które wpływają na polepszenie jakości życia oraz na innowacyjność gospodarki. Wszystkie one dają wymierne korzyści w postaci rozwoju i polepszenia komunikacji marketingowej, usprawnienia logistyki transportu, przejęcia przez roboty działań obarczonych ryzykiem dla człowieka czy poprawy obsługi klienta.

Jednocześnie proces ten niesie z sobą również zauważalne zagrożenia, zarówno dla pracowników, jak i dla klientów. Często wskazywanym problemem dotyczącym pracowników jest wpływ cyfryzacji na globalny rynek pracy, w tym na redukcje dotychczasowych stanowisk zajmowanych przez człowieka. Dotyczy to sfery produkcyjnej i usługowej. Część pracobiorców już musiała (lub będzie musiała w przyszłości) się przebranżowić, a niemal wszyscy jesteśmy zmuszani do ciągłego zdobywania nowych kompetencji w obszarach technologicznych czy programistycznych. Kto nie podoła tym wyzwaniom, narażony jest na „cyfrowe wykluczenie”, co oznacza ograniczony dostęp do określonych dóbr niezbędnych do normalnego funkcjonowania w społeczeństwie i na rynku pracy. Rozwój mobilnych technologii komunikacji może też sprzyjać zapotrzebowaniu na pełną dyspozycyjność pracowników, a to przekłada się na nieregularne godziny pracy, rozmycie granic między pracą a życiem prywatnym oraz oferowanie niestabilnych form zatrudnienia (Żmija, 2020).

Zagrożenia dotyczące konsumentów związane są natomiast ze zbieraniem i wykorzystaniem danych o nich, programowaniem autonomicznych urządzeń i środków transportu, wskazywaniem priorytetów w sytuacjach kryzysowych czy z opracowaniem algorytmów mających rozwiązywać problematyczne kwestie. Mogą one oddziaływać na sferę prywatności, podważać zasadę sprawiedliwości społecznej, osłabiać znaczenie ochrony życia i godności osoby oraz wynikających z niej praw.

Szybki i holistyczny charakter przemian związanych z cyfryzacją niesie więc z sobą wiele korzyści, ale również dylematów etycznych i społecznych, dotyczących obszaru działalności gospodarczej. Chcąc im sprostać, przedsiębiorstwa są zmuszane do opracowania spójnego systemu norm i zasad dotyczących zarządzania ich rozwojem i wdrażania technologii cyfrowej oraz zarządzania zbieranymi przez nie danymi. Pomocna w tym ma być koncepcja Corporate Digital Responsibility (CDR), stanowiąca adekwatną do zmieniającej się rzeczywistości cyfrowej konkretyzację CDR.

Dylematy etyczne związane z cyfryzacją szczególnie dotyczą mediów i procesu zarządzania nimi. Wpływ na to ma wrażliwość mediów na zmiany technologiczne, ale też zależność od zaufania odbiorców, które zdobywa się przede wszystkim poprzez kompetencje etyczne zarówno w kontekście aksjologicznym, jak i moralnym. W przeciwieństwie do innych branż korzystających z procesu cyfryzacji głównym zajęciem mediów stało się zbieranie danych, ich analiza i dystrybucja z uwzględnieniem preferencji odbiorców indywidualnych i komercyjnych, którzy mają 
konkretne oczekiwania. Dodatkowo stopień odpowiedzialności przedsiębiorstw medialnych jest większy niż innych branż ze względu na ich rolę i funkcje społeczne.

Uwzględniając więc specyfikę branży medialnej, warto przyglądnąć się ogólnej koncepcji CDR i przeanalizować zasadność jej ewentualnej implementacji w mediach. W tym celu dokonam przeglądu literatury i inicjatyw dotyczących CDR, a następnie przeanalizuję, jakie problemy etyczne i społeczne niesie z sobą proces cyfryzacji w mediach, by wskazać obszary, w których przedsiębiorstwa medialne mogłyby się wykazać dobrymi praktykami koncepcji CDR.

W tym miejscu należy jednak zaznaczyć, że dotychczas temat CDR był w polskiej literaturze rzadko poruszany ${ }^{1}$, a w kontekście mediów w ogóle nie stanowił przedmiotu analiz. Problem ten dotyczy również etyki zarządzania w mediach, którą obok etyki dziennikarskiej oraz etyki PR i reklamy należy postrzegać jako część koncepcji CDR. Prowadzone badania w obszarze ogólnie pojętej etyki mediów skupiają się bardziej na przekazie i procesie oraz kontekście jego tworzenia z perspektywy twórcy, a nie przedsiębiorcy medialnego.

Ciekawa i warta przywołania jest natomiast powstała w wyniku współpracy agencji badawczej SW RESEARCH oraz agencji public relations i digital marketing Procontent w 2019 roku inicjatywa „TOP CDR - Digitally Responsible Company”. Głównymi celami programu są:

- przygotowanie dokumentu dobrych praktyk na podstawie ankiety pracowników i pracodawców;

- nagradzanie dobrych praktyk w ramach CDR oraz promowanie dobrych modeli praktyk CDR;

- informowanie o możliwościach i zagrożeniach związanych z rozwojem technologicznym, które powinny być objęte przepisami dotyczącymi CDR (Dokument programowy TOP CDR, 2018).

W ramach projektu przygotowano raport: „Czy sztuczna inteligencja wygra z człowiekiem?” prezentujący obawy pracowników związane z automatyzacją i robotyzacją pracy, którym autorzy chcieli „rozpocząć debatę na temat cyfrowej rewolucji oraz cyfrowej odpowiedzialności firm w polskiej gospodarce” (Kubicz, 2019). W 2020 roku przeprowadzono również konkurs „TOP CDR - Firma Odpowiedzialna Technologicznie". Objęcie patronatu nad konkursem przez kilka ministerstw i szerokie zaangażowanie dużych firm wskazują, że problem został rozpoznany również przez polityków i ludzi biznesu.

Potwierdzają to także działania podejmowane przez Unię Europejską (UE). 19 lutego 2020 roku Komisja Europejska opublikowała dokument „Kształtowanie cyfrowej przyszłości Europy” (European Commission, 2020). Przedstawiono w nim nową strategię transformacji cyfrowej UE, której celem jest takie przeprowadzenie

1 Niepodejmowanie tego tematu dotyczy nie tylko literatury polskojęzycznej. Jak zauważają Lara Lobschat i współautorzy, od 1986 r. w ośmiu czołowych czasopismach opublikowano jedynie około 50 artykułów, które poruszają kwestie etyczne związane z badaniem systemów informacyjnych (2021, s. 876). Artykuły te nie zawierają jednak konkretnych porad w zakresie norm. 
procesu, by był on korzystny zarówno dla przedsiębiorstw, jak i dla Europejczyków i środowiska naturalnego. Opierać ma się natomiast na poszanowaniu europejskich wartości. Następnie, 9 marca 2021 roku, Komisja Europejska opublikowała dokument pt. „Cyfrowy kompas na rok 2030. Europejska droga w cyfrowej dekadzie" (European Commission, 2021). Wskazując na solidarność, troskę o dobrobyt i zrównoważony rozwój, przedstawiono w nim wizję i cele transformacji cyfrowej Europy do 2030 roku.

W założeniach wynikiem działań UE ma być przygotowanie przepisów w zakresie polityki cyfrowej i cyfrowych zasad. Dynamika procesu cyfryzacji jest jednak tak duża, że można przypuszczać, iż tak jak dotychczas i w przyszłości regulacje prawne nie będą $\mathrm{w}$ stanie nadążać za pojawiającymi się w jego przebiegu problemami. Rozwiązaniem dla powstającej w ten sposób luki ma być właśnie koncepcja CDR.

\section{Corporate Digital Responsibility - istota i zakres oddziaływania}

Chcąc podać definicję koncepcji cyfrowej odpowiedzialności biznesu, natrafimy na dość powszechny w naukach społecznych i humanistycznych problem związany $\mathrm{z}$ ich wielością i niejednoznacznością. Nie doszukamy się więc w literaturze jednej powszechnie przyjętej i wyczerpującej definicji tej inicjatywy. Znajdziemy natomiast wiele opisów zwracających uwagę na wybrane aspekty, które wspólnie dają pewien całościowy jej obraz.

Termin „cyfrowa odpowiedzialność biznesu” został wprowadzony w 2015 roku przez Tima Coopera, Jade Siu i Kuangyi Wei. Autorzy użyli go w artykule Corporate Digital Responsibility: Doing Well by Doing Good, w którym zadają główne pytanie: „Co oznacza odpowiedzialne zachowanie biznesowe w gospodarce cyfrowej?” (Cooper, Siu, Wei, 2015, s. 2). Lara Lobschat z zespołem (2021, s. 876) zwrócili uwagę na aksjologiczno-normatywny fundament funkcjonowania koncepcji CDR w przedsiębiorstwie i zdefiniowali ją jako „zbiór wspólnych wartości i norm kierujących działalnością organizacji w zakresie tworzenia i obsługi technologii cyfrowych i danych"2. Thierry Driesens (2017), wskazując podmioty chronione przez koncepcję CDR - do których zaliczył klientów oraz pracowników - i potrzebę solidarnego podejścia do nich, uważa, że cyfrowa odpowiedzialność biznesu „polega na upewnieniu się, że nowe technologie - a zwłaszcza dane - są wykorzystywane zarówno produktywnie, jak i mądrze". Christian Thorun, Sara Elisa Kettner i Johannes Merck (2018) rozszerzyli krąg beneficjentów o kolejne grupy, zwracając jednocześnie uwagę na główny cel CDR, którym ich zdaniem powinno być „zminimalizowanie negatywnych socjalnych i społecznych skutków cyfryzacji i cyfrowych

2 Jeżeli nie zaznaczono inaczej, wszystkie tłumaczenia tekstów w języku angielskim są mojego autorstwa. 
modeli biznesowych dla pracowników, dostawców, klientów, społeczeństwa i środowiska jako całości, a także wykorzystanie nowych możliwości cyfryzacji do osiągnięcia celów ogólnospołecznych". Artur Modliński (2019) podchodzi do problemu pragmatycznie i uważa, że korporacyjna odpowiedzialność cyfrowa to „wewnętrzne działania firmy w zakresie odpowiedzialności za dane, treść i interakcje $\mathrm{z}$ otoczeniem cyfrowym, (...) tworzenie i promowanie technologii, która ma pomóc jej odbiorcy". Vera Schneevoigt (2017) zwraca znów uwagę na naturę obowiązywalności CDR, określając ją „dobrowolnym zobowiązaniem”, które „zaczyna się od konieczności przestrzegania wymogów prawnych i standardów - dotyczących postępowania z danymi klientów, poufności czy własności intelektualnej - ale rozciąga się również na szersze względy etyczne i podstawowe wartości, którymi kieruje się organizacja”.

Michael Wade (2020) skupił się natomiast na określeniu zakresu cyfrowej odpowiedzialności biznesu i zasugerował, że „obejmuje ona cztery obszary - społeczny, ekonomiczny, technologiczny i środowiskowy, które należy połączyć pod jednym parasolem organizacyjnym”. Wspomniani na początku twórcy pojęcia CDR zdefiniowali z kolei pięć pól odpowiedzialności, których koncepcja CDR dotyczy. Są to: (1) odpowiedzialne obchodzenie się z danymi poprzez ich ochronę i bezpieczeństwo (digital stewardship); (2) przejrzystość w zakresie wykorzystania danych klientów (digital transparency); (3) wsparcie klienta w podejmowaniu decyzji dotyczących zdrowia, edukacji i finansów (digital empowerment); (4) sprawiedliwy podział zysków z użytkowania danych klientów (digital equity); (5) dostarczanie zbiorów danych do celów badawczych (digital inclusion) (Cooper, Siu, Wei, 2015, s. 2-3).

Mając na względzie powyższe definicje i odnosząc je do mediów, można przyjąć, że cyfrowa odpowiedzialność biznesu w mediach oznacza samodzielną decyzję organizacji medialnej (przedsiębiorstw medialnych i platform cyfrowych) o odpowiedzialnym podejściu do wdrażania oraz wykorzystania cyfryzacji i danych klienta, na każdym etapie produkcji i dystrybucji treści medialnych, opartą na przyjętych przez nią wartościach i normach, mającą na celu uzupełnienie braków prawnych, ochronę wszystkich jej interesariuszy i sprostanie stawianym jej przez społeczeństwo oczekiwaniom.

\section{CDR w przedsiębiorstwach medialnych - problemy etyczne i społeczne}

Po określeniu, jak rozumieć koncepcję CDR w mediach, przejdźmy do wskazania obszarów, w których mamy do czynienia z problemami etycznymi i społecznymi wywołanymi cyfryzacją, a których rozwiązaniem może być wypracowanie i zastosowanie dobrych praktyk CDR. By to uczynić, warto jednak wcześniej przypatrzyć 
się zmianom, jakie zaistniały w procesie produkcji oferty medialnej w wyniku zastosowania technologii cyfrowej.

W koncepcji rynkowej proces tworzenia produktu medialnego często opisywany jest za pomocą modelu łańcucha wartości, który przedstawia strategicznie istotne ogniwa działalności przedsiębiorstw medialnych. W swej pierwotnej wersji łańcuch wartości produktów medialnych tworzyły cztery zasadnicze elementy: wytwarzanie treści, przygotowanie treści, dystrybucja treści i organizacja odbioru. Cyfryzacja niewątpliwie zaburzyła tę prostą strukturę łańcucha, w której kontrola pozostawała często u przedstawicieli sektora (Küng, 2012, s. 33-34), a rola odbiorców ograniczała się przede wszystkim do konsumpcji proponowanych im produktów. Obecnie użytkownicy mediów biorą w coraz większym stopniu udział w tworzeniu nowych produktów i ponownym opracowaniu już istniejących. Dodatkowo postępująca w branży medialnej automatyka wykorzystuje również sztuczną inteligencję zarówno w planowaniu zadań, analizowaniu danych, jak i w tworzeniu materiałów komunikacyjnych. Zmiany te doprowadziły między innymi do zatarcia wyraźnych granic między produktem a usługą, informacją a reklamą, twórcą produktów medialnych a ich konsumentem (Grigore i in., 2017, s. 57), co niesie z sobą konkretne problemy etyczne i społeczne. Trzy główne obszary ich pojawienia się w kontekście gospodarczym mediów dotyczą: tworzenia produktu medialnego oraz praw autorskich i własnościowych, gromadzenia danych i ich przetwarzania oraz równości $\mathrm{w}$ dostępie do informacji i możliwości uczestniczenia w debacie.

\subsection{Tworzenie produktu medialnego oraz prawa autorskie i własnościowe}

Korzystanie z możliwości sztucznej inteligencji przy generowaniu tekstów przez światowe media stało się już nie tylko ciekawostką, ale stałą praktyką. Umożliwiły to rozwój technologiczny i odpowiednie oprogramowania przygotowane przez konkretne redakcje. BBC stworzyło Juicer, „The Washington Post” używa Heliogra$\mathrm{fu}$, a prawie jedna trzecia treści publikowanych przez Bloomberga jest generowana przez system o nazwie Cyborg (Chace, 2020). Ich zastosowanie wpłynęło wyraźnie na szybkość tworzenia informacji i stanowi realne wsparcie dla dziennikarzy. Jednocześnie rodzi też problemy. Jednym z nich jest możliwość wykorzystania systemów opartych na sztucznej inteligencji do kolportażu fake newsów, dezinformacji czy manipulacji. Dlatego też dobrą praktyką byłoby już na etapie tworzenia narzędzi zastosowanie zasady przejrzystości i odpowiedzialności, która zakładałaby budowę algorytmów generujących treści uwzględniające normy przyjęte wcześniej przez przedsiębiorstwa je tworzące i wykorzystujące.

Nie bez znaczenia są tu również bazy danych, z których korzystają przedsiębiorstwa. To na podstawie znajdujących się w nich informacji generowane są teksty. Wykorzystanie jednostronnych informacji będzie skutkowało jednostronnym przekazem. Skutkiem wyzyskiwania baz zawierających jedynie stare dane będzie przekaz niepełny i zafałszowany, na przykład nieuwzględniający rozwoju wrażliwości 
społecznej względem mniejszości, z jakim mamy przecież do czynienia w ostatnich latach. Nie bez znaczenia są również dane edukujące, wykorzystywane do uczenia algorytmu w celu wytworzenia modelu. Każdy z tych etapów prowadzących do wygenerowania przez algorytm tekstu związany jest z działaniem człowieka, które z perspektywy cyfrowej odpowiedzialności zakłada odniesienie do przyjętych przez przedsiębiorstwo norm i wartości.

Etyczne projektowanie i wykorzystanie technologii cyfrowych i związanych z nimi danych to nie tylko wyzwanie technologiczne (np. opracowanie algorytmów rozumowania etycznego). Wymaga raczej od organizacji opracowania kompleksowego, spójnego zestawu norm, osadzonych w ich kulturze organizacyjnej, w celu zarządzania rozwojem i wdrażania technologii i danych cyfrowych (Lobschat i in., 2021, s. 876).

Inne problemy generowane przez dziennikarstwo algorytmiczne związane są z wypieraniem przez nie człowieka będącego dotychczas jedynym autorem treści medialnych. Pojawiające się w tym kontekście obawy nie dotyczą jedynie utraty miejsc pracy, co jest znamienne dla innych branż, ale również dylematów co do podmiotu odpowiedzialności za skutki wywołane przez przygotowane i dystrybuowane treści. Z etycznego punktu widzenia ciągle podmiotem odpowiedzialności pozostaje człowiek jako osoba zdolna do refleksyjnego myślenia. Oznacza to, że reprezentanci przedsiębiorstw nie powinni uciekać od odpowiedzialności, gdy publikowana jest treść generowana przez algorytm. Za działaniami tych ostatnich stoi człowiek, również wtedy gdy ich struktura i sposób działania są trudne do ustalenia.

Zaangażowanie użytkowników mediów w proces tworzenia ich produktów budzi wątpliwości co do praw autorskich i własnościowych. Dotychczas zagadnienie to opracowywane było przede wszystkim w kontekście problemów związanych z piractwem medialnym, procederem nielegalnego kopiowania i rozpowszechniania materiałów chronionych prawami autorskimi oraz naruszaniem własności intelektualnej, w wyniku których dochody traciły firmy czy, szerzej, gospodarka (np. PwC Polska Sp. z o.o., 2014). Mniej uwagi poświęcono natomiast prawom użytkowników biorących udział w tworzeniu produktów medialnych. Wypracowanie dobrych zasad miałoby na celu uniknięcie poczucia wyzysku, jakiego doświadczyli chociażby blogerzy Huffington Post, którzy już w 2012 roku stwierdzili, że „zostali zamienieni we współczesnych niewolników na plantacji Arianny Huffington" (Kreft, 2013, s. 160). Od tego czasu problem ten jedynie się nasilił. Odpowiedzialną praktyką byłoby włączenie użytkowników do grupy beneficjentów.

Kwestia praw autorskich dotyczy również treści generowanych przez algorytmy. Podobnie jak w przypadku odpowiedzialności za skutki wywołane przez wytwarzane przez nie produkty medialne, tak i w tej sytuacji - to przedsiębiorstwom, konkretnie ich reprezentantom, przysługują prawa autorskie i własnościowe. 


\subsection{Magazynowanie danych i ich przetwarzanie}

Pojawieniu się mediów cyfrowych towarzyszy rozwój mediów społecznościowych, a później również komunikatorów. Służące interakcji, dysponujące rozbudowanym zestawem narzędzi komunikacyjnych media społecznościowe stały się nie tylko silnie eksploatowanym kanałem komunikacji, ale także nowym obszarem działalności gospodarczej. W przyjętych przez nie modelach biznesowych stosunkowo rzadko spotykamy sytuację, że źródła swego dochodu wiążą one na przykład ze sprzedażą abonamentów członkostwa. Większość z nich źródła finansowania łączy z gromadzeniem danych użytkowników i zarządzaniem nimi. Przekazywane w wyniku aktywności użytkowników informacje stały się dla przedsiębiorstw medialnych źródłem zdobywania własnej przewagi konkurencyjnej i „produktem” podlegającym wymianie handlowej, którego właścicielem są platformy i serwisy społecznościowe. Ich darmowa usługowa działalność jest podstawą tworzenia monetyzowanego produktu, którym są odpowiednio do potrzeb klienta sformatowane informacje o użytkownikach. Wymaga to odpowiedzialności już na etapie projektowania modeli gromadzenia danych konsumenckich oraz modeli analitycznych wykorzystywanych do ich przetwarzania.

Prowadzona w tym obszarze przez niektóre firmy działalność budzi wątpliwości w perspektywie cyfrowej odpowiedzialności biznesu. Najbardziej znanym przykładem było wykorzystanie danych z Facebooka przez Cambridge Analytica w czasie kampanii prezydenckiej w USA w roku 2016. Skutkiem tego była akcja \#Faceblock, w której użytkownicy wyrazili swoje niezadowolenie wobec praktykowanego sposobu zarządzania danymi przez Facebooka i bojkotowali największy serwis społecznościowy, powszechnie zachęcając do usuwania profili.

Akcja ta wykazała zarówno rosnącą świadomość wśród użytkowników, jak i ich oczekiwania względem przedsiębiorstw medialnych magazynujących dane. Prowadzona w tym kontekście dyskusja pokazuje, że sposób i możliwości ich wymiany przez firmy nie mogą podlegać jedynie zasadom wolnego rynku, szczególnie że media społecznościowe stanowią również miejsce dzielenia się informacjami wrażliwymi. CDR postuluje w tym zakresie większą odpowiedzialność mediów i szanowanie prawa do prywatności użytkowników, którzy im zaufali. Ponadto dobrą praktyką wskazywaną przez CDR jest również zapewnienie odpowiedniego bezpieczeństwa danym. Zbierając je, media biorą na siebie odpowiedzialność za ich ochronę zarówno przed podmiotami nieuprawnionymi do ich posiadania, jak i tymi, które wprawdzie mają prawo je posiadać, ale chcą je wykorzystywać w sposób nieuprawniony.

Kontrowersje budzi również problem zarządzania własnym kontem, a w szczególności możliwość zamknięcia go w dowolnym momencie przez użytkownika usług mediów społecznościowych. Obok problemów udostępniania i handlu danymi koncepcja CDR wykazuje też dobre praktyki - na przykład umożliwienie użytkownikowi przez media społecznościowe jako usługodawcę swobodnego dostępu 
do własnych danych, zarządzania nimi, łącznie z prawem rezygnacji z ich udostępnienia.

Wprawdzie rozporządzenie unijne o ochronie danych osobowych RODO stwarza oczywiście ramy prawnej ochrony osób fizycznych w kontekście przetwarzania ich danych, niemniej jednak media potrzebują do prowadzenia swojej działalności zaufania użytkowników, kultury organizacyjnej i norm, które będą kształtowały ich zachowania na różnych poziomach funkcjonowania. Biorąc pod uwagę różnorodność użytkowników i ich nastawienia do prywatności, wprowadzenie przejrzystych zasad magazynowania i wykorzystywania danych może przyczynić się również do zwiększenia zaufania użytkowników.

\subsection{Równość w dostępie do informacji i możliwości uczestniczenia w debacie}

GAFAM to, jak wiadomo, akronim pięciu amerykańskich spółek technologicznych: Google, Apple, Facebook, Amazon i Microsoft, które pod względem kapitalizacji rynkowej tworzą pierwszą piątkę spółek na giełdzie NASDAQ. Ich siła rynkowa oparta jest na monopolistycznej kontroli danych i pozycji lidera w dziedzinie cyfrowej i sztucznej inteligencji. Zdobyta pozycja wydaje się niezagrożona, a kolejne operacje integracyjne, również na rynku mediów, pozwalają przypuszczać, że przy dalszym braku istotnej kontroli ze strony państw lub organizacji międzynarodowych przynajmniej w najbliższej przyszłości ich dominacja technologiczna i finansowa może się jeszcze umacniać. Tymczasem firmy te są głównymi pośrednikami społecznymi i gospodarczymi, dostarczycielami niezbędnych usług, produktów i infrastruktury, co w kontekście ich działań rodzi obecnie coraz większe wątpliwości i obawy natury etycznej i społecznej.

Wielka piątka poprzez posiadane platformy społecznościowe i wyszukiwarki internetowe stała się głównym źródłem dostarczania informacji wpływających na sposób myślenia ich użytkowników. Często jednak użytkownicy ci nie są świadomi procesów filtracji i modyfikacji prezentowanych na tych platformach treści. Procesy te nie budziłyby wątpliwości, gdyby ich celem była pomoc w dotarciu użytkownika konfrontowanego $\mathrm{z}$ nadmiarem informacji do tych $\mathrm{z}$ nich, które odpowiadają jego zainteresowaniom czy potrzebom. Wątpliwości i obawy budzi jednak działanie platform społecznościowych wyłącznie w celach komercyjnych, politycznych czy ideologicznych. Tworzenie przez platformy algorytmów kontrolujących, jakie treści, w jakiej kolejności i w jakim czasie wyświetlają się poszczególnym użytkownikom prowadzi do ograniczenia ich prawa do swobodnego dostępu do informacji. Ponieważ zasoby finansowe i technologiczne GAFAM sprawiają, że firmy te zawsze będą miały możliwość opracowania algorytmów, które wpłyną na sposób naszego myślenia, CDR widzi konieczność odwołania się do ich odpowiedzialności.

Innym problemem postrzeganym przez niektórych jako zagrożenie prawa do wolności wypowiedzi są ustalone przez platformy społecznościowe zasady publikacji treści i blokowania kont osób, które zdaniem ich administratorów prawa te 
naruszyły. Platformy społecznościowe mogą za ich pomocą ograniczać, kontrolować i cenzurować wypowiedzi w stopniu większym niż podmioty rządowe. Dodatkowo ich skuteczność jest zdecydowanie większa, gdyż nikt nie będzie udowadniał im przestępstwa $\mathrm{w}$ długim procesie sądowym. Umożliwienie platformom cenzurowania treści czy osób jest konsekwencją przyjęcia, że wolność słowa nie oznacza pełnej swobody wypowiedzi i jest ograniczona chociażby poszanowaniem godności osoby czy brakiem zgody na nawoływanie do przemocy. Stanowisko takie prezentuje chociażby Rada Nadzorcza Facebooka, która 7 maja 2021 roku podtrzymała trwające od początku tego roku zawieszenie kont prezydenta Donalda Trumpa na swoich platformach, stwierdzając, że posty byłego prezydenta mogą raczej zwiększyć niż zmniejszyć ryzyko stosowania przemocy, szczególnie wobec osób biorących udział w szturmie na Kapitol. Posiadanie tak dużej władzy w ograniczaniu możliwości swobodnego wypowiadania się na platformach, dla których brak realnej alternatywy, wiąże się z odpowiedzialnością, którą również postuluje CDR.

\section{Zakończenie}

Przedstawione powyżej obszary i konkretne problemy etyczne oraz społeczne związane z cyfryzacją mediów ukazują jedynie część podjętego zagadnienia. Już te omówione sytuacje pokazują pilność i potrzebę reakcji. W związku z nienadążaniem regulacji prawnych za tempem procesu cyfryzacji w mediach i pojawiających się dylematów proponowana koncepcja CDR, widząca szanse w odpowiedzialnym kształtowaniu kultury organizacji, wydaje się słusznym kierunkiem. Wynikające z niej całościowe ujęcie odpowiedzialności biznesu, oznaczające wzięcie przez firmy odpowiedzialności za konsekwencje swoich procesów biznesowych, produktów i usług dla pracowników, dostawców, klientów, społeczeństwa jako całości i środowiska rokuje również większe szanse zaradzenia problemom niż reagowanie fragmentaryczne w poszczególnych obszarach. Praktyczne wskazówki oparte na fundamencie etycznego życia społecznego, które proponuje CDR, nie powinny też być postrzegane jako ograniczenia i wiązać się ze stratą dla przedsiębiorstwa. Oczekiwania społeczne co do odpowiedzialnego podejścia do procesu cyfryzacji w mediach są coraz częściej i coraz głośniej artykułowane. Pozytywna odpowiedź na nie będzie wzmacniać zaufanie do przedsiębiorstw je wprowadzających, które w kontekście mediów stanowi niewątpliwie ważny kapitał. 


\section{Bibliografia}

Chace C. (2020). The Impact of AI on Journalism. Pobrane z: https://www.forbes.com/sites/calumchace/2020/08/24/the-impact-of-ai-on-journalism/?sh=1c8fac4c2c46 (dostęp: 24.04.2021).

Cooper T., Siu J., Wei K. (2015). Corporate Digital Responsibility: Doing Well by Doing Good. Accenture. Pobrane z: https://www.accenture.com/_acnmedia/Accenture/Conversion-Assets/Outlook/Documents/2/Accenture-Corporate-Digital-Responsibility-Web-PDF-V2.pdf (dostęp: 21.03.2021).

Dokument programowy TOP CDR (2018). Pobrane z: http://www.wns.us.edu.pl/images/Dokument_programowy_TOP_CDR.pdf (dostęp: 7.04.2021).

Driesens T.(2017). The Rise ofCorporateDigitalResponsibility.Pobrane z: https://www.i-cio.com/ management/best-practice/item/the-rise-of-corporate-digital-responsibility (dostęp: 7.04. 2021).

European Commission (2020). Shaping Europe's Digital Future. Pobrane z: https://ec.europa. eu/info/sites/default/files/communication-shaping-europes-digital-future-feb2020_en_4. pdf (dostęp: 8.04.2021). DOI: 10.2759/091014.

European Commission (2021). Cyfrowy kompas na 2030 r. Europejska droga w cyfrowej dekadzie. Pobrane z: https://eur-lex.europa.eu/legal-content/pl/TXT/?uri=CELEX\%3A52021DC0118 (dostęp: 8.04.2021).

Facebook (2012). Pobrane z: https://www.sec.gov/Archives/edgar/data/1326801/000119312 512235588/d287954ds1a.htm (dostęp: 7.04.2021).

Grigore G., Molesworth M., Watkins R. (2017). New Corporate Responsibilities in the Digital Economy. W: A. Theofilou, G. Grigore, A. Stancu (red.). Corporate Social Responsibility in the Post-Financial Crisis Era. Cham: Springer International Publishing, s. 41-62. DOI: 10.1007/978-3-319-40096-9_3.

Kubicz I. (2019). Czy sztuczna inteligencja wygra z człowiekiem? Raport programu Cyfrowej Odpowiedzialności Biznesu. Pobrane z: https://topcdr.pl/2019/12/16/raport-cyfrowa-odpowiedzialnosc-biznesu/ (dostęp: 7.04.2021).

Küng L. (2012). Strategie zarządzania na rynku mediów. Przeł. P. Jabłoński. Warszawa: Wolters Kluwer Polska.

Kreft J. (2013). Zarządzanie wspóttworzeniem wartości w mediach - od łańcucha do konstelacji. „Problemy Zarządzania”, 11, 4(44), s. 160-171.

Lobschat L., Mueller B., Eggers F. [i in.] (2021). Corporate Digital Responsibility. „Journal of Business Research", 122 (January), s. 875-888.

Modliński A. (2019). Raport programu Cyfrowej Odpowiedzialności Biznesu. Pobrane z: https:// topcdr.pl/2019/12/16/raport-cyfrowa-odpowiedzialnosc-biznesu/ (dostęp: 7.04.2021).

PwC Polska Sp. z o.o. (2014). Analiza wpływu zjawiska piractwa treści wideo na gospodarkę $w$ Polsce. Pobrane z: https://www.pwc.pl/pl/publikacje/piractwo/analiza_wplywu_zjawiska_piractwa_tresci_wideo_na_gospodarke_w_polsce_raport_pwc.pdf (dostęp: 7.04.2021).

Schneevoigt V. (2017). The Rise of Corporate Digital Responsibility. Pobrane z: https://www.i-cio.com/management/best-practice/item/the-rise-of-corporate-digital-responsibility (dostęp: 7.04.2021).

Thorun C. (2018). Corporate Digital Responsibility: Unternehmerische Verantwortung in der digitalen Welt. W: C. Gärtner, C. Heinrich (red.). Fallstudien zur Digitalen Transformation. Wiesbaden: Springer Gabler, s. 173-191. DOI: 10.1007/978-3-658-18745-3_9.

Thorun C., Kettner S.E., Merck J. (2018). Ethik in der Digitalisierung: Der Bedarffür eine Corporate Digital Responsibility. Bonn: Friedrich-Ebert-Stiftung, Abteilung Wirtschafts- und 
Sozialpolitik (WISO direkt, 17/2018). Pobrane z: http://library.fes.de/pdf-files/wiso/ 14691.pdf (dostęp: 7.04.2021).

Wade M. (2020). Corporate Responsibility in the Digital Era. Pobrane z: https://sloanreview. mit.edu/article/corporate-responsibility-in-the-digital-era/ (dostęp: 7.04.2021).

Żmija K. (2020). Corporate Digital Responsibility - nowy wymiar społecznej odpowiedzialności przedsiębiorstw. Pobrane z: https://rev4.uek.krakow.pl/blog/corporate-digital-responsibility-nowy-wymiar-spolecznej-odpowiedzialnosci-przedsiebiorstw-wpis-blog/ (dostęp: 7.04.2021). 